\title{
SOCIALIZATION OF REGIONAL REGULATIONS OF TELUK BINTUNI REGENCY NUMBER 1 YEAR 2019 DEALING RECOGNITION AND PROTECTION OF TRADITIONAL LAW COMMUNITIES IN TELUK BINTUNI DISTRICT
}

\author{
Leny NADRIANA ${ }^{1}$, St. Laksanto UTOMO ${ }^{*}$, Gatot Rambi HASTORO \\ ${ }^{1,3}$ Sahid University, Indonesia \\ ${ }^{2}$ Sang Bumi Rawa Jurai University, Indonesia \\ *laksanto@gmail.com
}

\begin{abstract}
This activity was carried due to the issuance of Regional Regulation of Teluk Bintuni Regency Number 1 of 2019 dealing with Recognition and Protection of Indigenous Law Communities in Teluk Bintuni Regency. With the issuance of the regional regulation, consequently the life system, the rights of indigenous peoples that have existed for generations have been recognized by the government and can be carried out in a corridor that is in accordance with general norms, in the field implementation the application of this rule has not been fully understood by the local indigenous community. with the mandate of the 1945 Constitution of the Republic of Indonesia that the State recognizes and respects and protects customary law community units and their traditional rights as long as they are still alive and in accordance with community development and the principles of the Unitary State of the Republic of Indonesia through the recognition and protection of customary law communities. Weak socialization and public understanding of the importance of this Regional Regulation (PERDA) so that this activity aims at 1). provide an understanding of what it means to protect indigenous peoples and their rights in the community in accordance with their local wisdom contained in the PERDA, 2) To encourage local governments intensely and routinely to socialize this PERDA so that it is conveyed to indigenous peoples. The conclusion of this socialization activity received a positive response from the community, marked by the open understanding of indigenous peoples that their rights have been stated in the PERDA
\end{abstract}

Keywords: Customary Law Community, Protection, Regional Regulation, Teluk Bintuni Regency

\section{BACKGROUND}

Teluk Bintuni Regency is a regency in West Papua Province which has 7 (seven) tribes, including: a). Kuri tribe, b). Wamesa tribe, c). Irorutu tribe, d). Sebyar tribe, e). Simuri tribe, f). Sougb tribe, and g). Moscow Tribe. Of these seven tribes, they have traditional rules that have been passed down from generation to generation which have been used to regulate their daily life.

Customary institutions are one element of the existence of an indigenous people because it is an important point for indigenous peoples that existed long before the establishment of the Unitary State of the Republic of Indonesia, efforts to restore the position of indigenous peoples as public legal entities that are part of the government are contained in Law No. 2014 on the Village. Recognition and protection of the rights of indigenous peoples in Papua is one of the political steps that must be taken by the Papuan provincial government in carrying out the mandate of the 1945 Constitution in the context of fulfilling human rights and obligations that must be carried out by the State.

Recognition and protection of the rights of indigenous Papuans is an urgent need so that they can enjoy their rights which are inherent and rooted in their political system, economy, social and cultural structure, religious traditions, histories and views of life as well as customary law. Therefore, a regional regulation is needed that regulates the recognition and protection of indigenous peoples.

In accordance with the mandate of the 1945 Constitution of the Republic of Indonesia, that the state recognizes and respects and protects customary law community units and their traditional rights as long as they are still alive and in accordance with community development and the principles of the Unitary State of the Republic of Indonesia through the recognition and protection of indigenous peoples, on the other hand. another based on the decision of the constitutional court case number 35/PUU-X/2012 regarding the review of law number 41 of 1999 on Forestry, that in order to ensure the existence of a just legal certainty for Indigenous Law Communities and their traditional rights can be regulated in regional regulations, the existence of the customary law community in Teluk Bintuni district still exists and is part of the community component whose existence must be recognized and respected by the state.

With the issuance of a regional regulation concerning the recognition and protection of indigenous peoples in Teluk Bintuni Regency number 1 of 2019 concerning Recognition and Protection of Indigenous Law Communities in Teluk Bintuni Regency, it is necessary to disseminate information to indigenous peoples in the Teluk Bintuni Regency area.

\section{METHOD}

Regional Regulation of Teluk Bintuni Regency Number 1 of 2019 Recognition and Protection of Indigenous Law Communities in Teluk Bintuni Regency has not been conveyed to the customary law community to the fullest so that if there are problems that arise, the community cannot resolve them in accordance with the PERDA. Over time, the role of the region regarding regional development efforts is prone to conflict with these indigenous peoples.

The method used is to provide socialization/ explanation to indigenous peoples and students of the Bintuni College of Law. In its implementation, this activity is carried out to provide socialization to participants about the recognition and protection of indigenous peoples. 
The target in this activity is the indigenous people of Teluk Bintuni, students of the Bintuni School of Law as a university in the field of law in the area of activity, it is hoped that in the future there will be a change in the mindset of indigenous peoples in knowing local regulations for the recognition and protection of indigenous peoples in Teluk Bintuni Regency. The population in this activity are traditional leaders in the Bintuni district, namely the Kuri tribe, Wamesa tribe, Irorutu tribe, Sebyar tribe, Simuri tribe, Sougb tribe, and Moskona tribe. become ambassadors in the delivery of information on regional regulations on the recognition and protection of indigenous peoples in Teluk Bintuni district to their peers, especially indigenous peoples.

This core activity took place on Saturday and Sunday, 22 to 23 February 2020 at the Bintuni College of Law. In addition to the instructor's support, this community service activity was also accompanied by the Head of the West Papua Province Legal Bureau, as well as the Deputy Head of Academic Affairs at the Bintuni Law School. Because indigenous peoples have different levels of education, the activities do not start with pre-test and post-test, but direct counseling and discussion.

The steps that have been carried out in this community service activity are as follows:

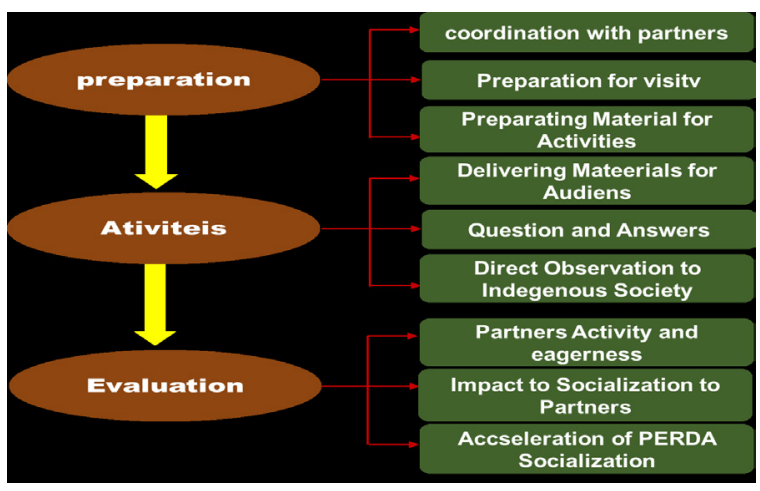

Figure 1. schedule of activities

\section{RESULTS AND DISCUSSION}

In the implementation of this activity, the implementers of community service activities work closely with the Bintuni Law School and the Law Bureau of West Papua Province. The form of activity was carried out in the form of a discussion led by the moderator, vice chairman of the academic field of the law high school, this activity was attended by 48 participants and came from indigenous community leaders, traditional leaders and students, especially final year students.

Before the activity begins, the activity implementer coordinates with the Bintuni Law School as a place for the activity to be carried out, besides that it also coordinates with the West Papua provincial law firm as the legal area for the activity, things to do in the form of administrative requirements, materials to be given to participants, and accommodation. After the implementation, the implementing team then visited the location, namely the Bintuni School of Law to provide guidance / socialization on regional regulations for the recognition and protection of indigenous peoples in Teluk Bintuni district and the form of its implementation. The socialization was carried out by giving lectures with topics that had been prepared followed by a question-and-answer session, in this session things happened as expected the questions asked by the participants on average showed their lack of knowledge about the regional regulations.

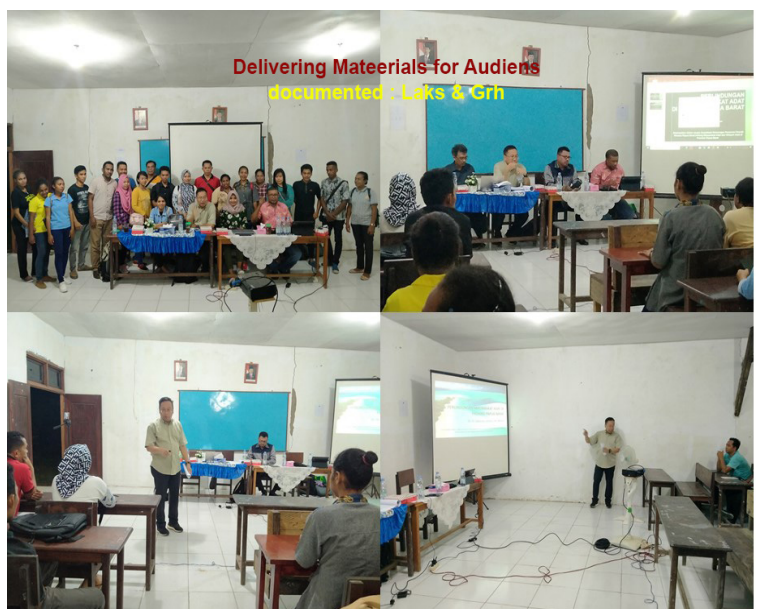

Figure 2.Deivering Materials for Audience

From a number of questions asked, it can be understood that the participants did not understand the regional regulations because they had not been socialized which basically required cooperation from all parties, not only the government but also the community, especially indigenous peoples, but more importantly starting from themselves. In the implementation of the socialization, the implementing team can obtain information that some of the participants already know that the regional regulations have been issued by the local government but have not been socialized so that the implementation of regional regulations has not been maximized and hit the target, this indicates that the information absorbed by them through the media is not good and fast because on average indigenous peoples are people who are not familiar with communicating with the apparatus in this case government officials and the distance between ethnic groups is relatively far and quite difficult to reach by existing transportation facilities.

The materials presented in the socialization of regional regulations regarding the recognition and protection of indigenous peoples in Teluk Bintuni district include 1). Traditional rights which are communal or individual rights of origin inherent in customary law communities, originating from their social and cultural systems, especially rights to land, territory and natural resources, 2). Customary law which is an unwritten rule or norm that lives in the Customary Law Community, regulates, binds and is maintained, and has sanctions, 3 ). Customary institutions are organizational devices and/or customary government institutions that grow and develop along with the history of customary law communities to regulate and resolve various life problems in accordance with applicable customary law, 
4) Customary areas, hereinafter referred to as ulayat rights, are living spaces where the existence of customary law communities consists of land, water, and waters along with all the natural resources contained therein which are determined with certain boundaries, which control, manage and its utilization is carried out according to customary law, 5) Customary land which is a parcel of land contained within a customary territory whose type and arrangement are determined based on customary law, 6). Customary forest which is a forest area and all forest resources located within the territory of customary law communities, 7) Mapping of customary areas is used for a process of translating landscapes into cartographic form based on the history of origin and governance of a customary area in accordance with the system. knowledge and practices that apply in the customary law community concerned, 8). Local wisdom is ideas, values, and views that are wise, traditional knowledge, full of wisdom, good values that live and develop in a community of customary law communities and are obeyed by members of the community, 9). The customary court is a judicial institution that lives in the daily practice of customary law communities and functions to resolve customary disputes based on customary law and/or new mutually agreed norms, 10). The Indigenous Law Community Consultative Body, hereinafter abbreviated as MMHA, is a body formed and jointly determined by tribal customary institutions whose membership comes from representatives of each customary law community and is tasked with facilitating and mediating conflict resolution between customary law communities and between customary law communities and other parties. other outside the customary law community and/or to discuss the interests of the customary law community and its achievements.

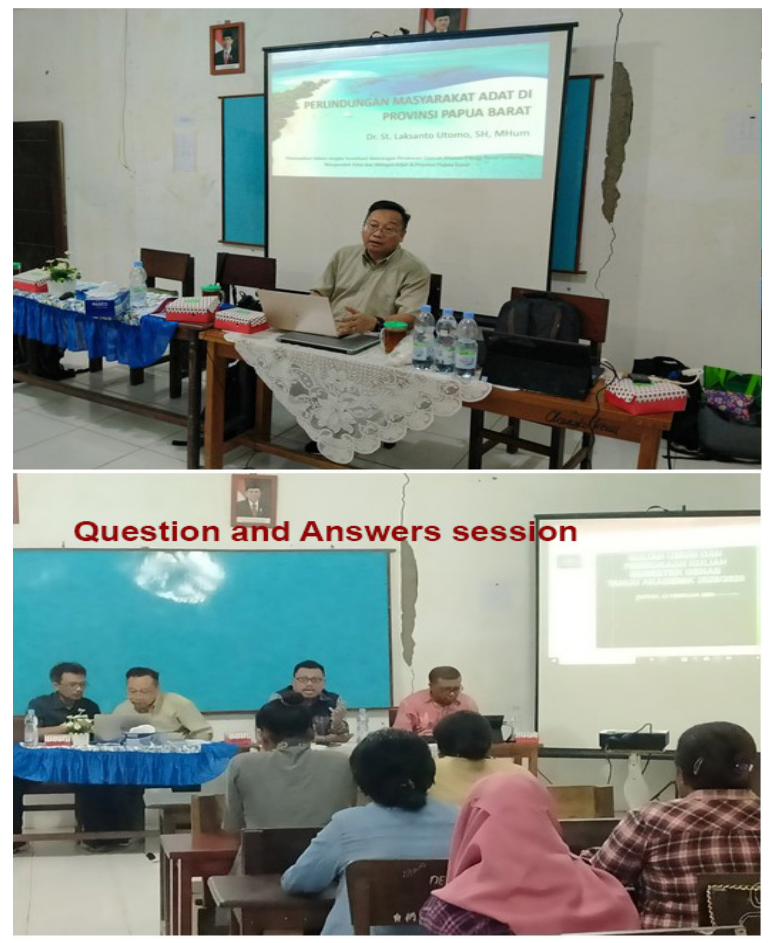

Figure 3. Question and Answers Session
The rights of indigenous peoples themselves include a). customary rights; b). clan rights over land and natural resources and their utilization, $\mathrm{c}$ ). the right to obtain compensation from the use of natural resources by outsiders, d). the right to obtain the sharing of benefits from natural resources, genetic resources and traditional knowledge by outsiders, e). the right to take care of oneself, f). the right to exercise customary law and justice, g). the right to spirituality and culture, and h). other rights regulated in laws and regulations.

Meanwhile, the obligations of customary law communities include: a). obey and implement the values and norms of customary law, b). comply with and carry out the agreements that have been made with other parties, and e). other obligations regulated in laws and regulations. Recognition and protection of indigenous peoples aims to: a). provide legal certainty regarding the existence, customary territory, customary forest and rights of indigenous peoples, b). strengthen access, participation and improve the welfare of indigenous peoples to land, water and natural resources through customary institutions, c). realize the management of customary areas in a fair, beneficial and sustainable manner based on customary law; d). organize customary institutions and customary leadership, e). realizing a democratic social life and mutual respect and acknowledgment of socio-cultural differences, f). realizing development policies that recognize and protect the rights of indigenous peoples in Teluk Bintuni district, and g). realizing dispute resolution based on the recognition and protection of the rights of indigenous peoples and their customary law.

\section{THE EXISTENCE OF TRADITIONAL LAW COMMUNITIES}

The Customary Law Community in Teluk Bintuni Regency meets the general criteria a). consists of a community whose citizens feel as a group because of the values that are maintained together, $b$ ). have traditional institutions that grow traditionally, c). own assets and/ or customary objects as ancestral heritage and d). have customary law norms that are still valid; and e. have a certain customary territory.

Meanwhile, residents of the Bintuni customary law community include a). people who are born, live, and settle in Teluk Bintuni Regency, b). people who obey the customary law in force in the Customary Territory in Teluk Bintuni Regency, c). people who carry out their traditional and cultural rituals and d). people who have lived and developed together for generations in Teluk Bintuni Regency

\section{THE RIGHTS AND OBLIGATIONS OF INDIGENOUS LAW COMMUNITIES}

The Regional Government recognizes, respects, and protects the rights of the Indigenous Peoples in Teluk Bintuni Regency which includes: a. customary rights, 
b. clan rights to land and natural resources and their utilization, c. the right to obtain compensation from the use of natural resources by outsiders, $d$. the right to obtain benefit sharing from natural resources, genetic resources and traditional knowledge by outsiders, e. the right to take care of oneself, f. the right to exercise customary law and justice, g. the right to spirituality and culture; and h. other rights regulated in laws and regulations. Meanwhile, the obligations of customary law communities include: a. obey and implement the values and norms of customary law, b. obey and carry out the agreements that have been made with other parties and c. other obligations regulated in laws and regulations.

The existence or existence of customary rights (traditional of indigenous peoples is still evident in the existence of communities in Indonesia. However, the customary rights of indigenous and tribal peoples are still recognized in the Indonesian legal system; this can be seen in the regulations in the applicable laws and regulations in Indonesia.

\section{TRADITIONAL REGION}

Customary territory consists of land, forest, waters, mining materials, minerals and other natural resources attached to it as a unitary area of life of the Customary Law Community. It consists of a. traditional use areas and b. areas that are considered important to be specifically protected for their use. The customary area is utilized for a. cultural interests, b. economic interests and fulfillment of daily needs and c. traditional conservation interests.It is owned by indigenous communities and administered in accordance with their customs, as opposed to statutory tenure usually introduced during the colonial periods. Common ownership is one form of customary land ownership.

The boundaries of the customary area are determined by the Customary Law Community in Teluk Bintuni Regency based on the history of origin, and agreed upon by the community whose territory is directly adjacent.

The customary area of the Indigenous Peoples is determined by the Decree of the Regent to be integrated into the Bintuni Bay Regency Spatial Plan and other policies that do not conflict with the Regional Spatial Plan.

\section{TRADITIONAL INSTITUTIONS}

Customary institutions are tribal customary institutions and clan institutions. Tribal customary institutions and clan adat institutions carry out the customary mandate of tribal members and members of their clans. And the Regional Government recognizes, protects and empowers traditional institutions that have existed for generations and/or forms new customary institutions in the Customary Law Community in accordance with local customary law based on customary agreements.

Customary institutions are domiciled as the executor of the authority of the Customary Law Community to a. administer and regulate the control, management and utilization of customary areas and assets; b. implement customary law and justice and c. representing the Indigenous Law Community in conducting legal relations with outside parties.

\section{EMPOWERMENT}

Empowerment is carried out by the Regional Government. The Regional Government in its implementation prepares adequate personnel and budget and provides an information service center regarding the Indigenous Law Community in Bintuni Bay.

In the development decision-making process, the Regional Government is carried out by encouraging the involvement of all elements of society, especially women and youth by paying attention to increasing the capacity of traditional institutions, utilizing local potentials, welfare goals, and respecting customary values and rules.

In the event that the Indigenous Law Community and/or parties outside the customary law community intend to cooperate in the field of empowerment, the local government provides facilities in the form of:

a. legal assistance to assist Indigenous Law Communities; b. preventive action for an activity that disturbs the integrity and/or causes damage to customary territory, c. special services in the fields of education, health, economy and women, d. general administrative services related to their citizenship rights and e. services in the field of empowerment of Indigenous Law Communities and the environment.

\section{MANAGEMENT AND USE OF NATURAL RESOURCES}

The management and utilization of natural resources is carried out in a fair and sustainable manner, respecting the local wisdom of the customary law community, paying attention to the traditional rights of the customary law community;

As well as providing the maximum benefit for the welfare and sustainability of the Indigenous Law Community and the environment.

In the event that the Customary Law Community and/or parties outside the Customary Law Community intend to cooperate in the utilization of natural resources for economic and environmental purposes, the local government shall provide facilities, among others: a. education and training, b. Startup Capital; c. market access, d. supporting facilities and infrastructure, e. administration and licensing, and f. construction and protection.

The management and utilization of these natural resources is carried out based on the principle of Free, Prior and Informed Consent (FPIC).

\section{DISPUTE RESOLUTION}

The Regional Government respects and recognizes customary courts and decisions of customary courts to 
resolve disputes between members of the Indigenous Law Community or violations committed by outside parties within the customary territory and assist the resolution of disputes between the Indigenous Law Community through mediation.

In the event that the dispute resolution does not reach a settlement, then the dispute is resolved through the general court. In the event that there is a dispute between the customary law community and institutions and/or legal entities, the settlement is carried out by deliberation and consensus and if an agreement is not reached, the dispute is resolved through a general court.

\section{TRADITIONAL LAW COMMUNITY CONSULTANCY AGENCY \\ The Indigenous Law Community Deliberation} Body is formed by a tribal Customary Institution consisting of representatives of 2 (two) people from each tribe, the Management of the Indigenous Law Community Deliberation Board serves for 3 (three) years and then a new election is held, in the election of the Management of the Community Deliberation Board Customary law is technically regulated by a district head regulation.

The Indigenous Law Community Deliberation Body establishes a Secretariat, to support the implementation of its functions and authorities, the Indigenous Law Community Deliberation body is domiciled in the district capital and the Indigenous Law Community Deliberation Board is established by a Regent Decree.

From the implementation of these community service activities, local regulations have been socialized as well as indigenous peoples have begun to understand that their existence, rights and obligations are protected by law so that their activities in daily life can use the rules they have made from generation to generation and are believed to be still refers to social norms in general.

From the implementation of these community service activities, local regulations have been socialized as well as indigenous peoples have begun to understand that their existence, rights and obligations are protected by law so that their activities in daily life can use the rules they have made from generation to generation and are believed to be still refers to social norms in general.

\section{CONCLUSION}

Recognition of indigenous peoples in the regulatory framework in the regions as a forum for carrying out social empowering or strengthening communities to manage and protect their customary territories, communities as subjects of development, especially indigenous peoples, must of course pay attention to their rights in every development process, considering their involvement and participation. they are in development is very necessary.

The Regional Government recognizes, protects and empowers traditional institutions that have existed for generations and/or forms new customary institutions in customary law communities according to local customary law based on customary agreements.

In the future, the settlement area for the customary law community in Teluk Bintuni district can be designated as a traditional village in accordance with the provisions of the legislation and provide legal certainty regarding the existence, customary territory, customary forest and rights of customary law communities as well as strengthening access, participation and improving welfare.

\section{ACKNOWLEDGEMENT}

Community service implementers express their highest appreciation to all parties who have provided assistance for this activity, namely: 1). Head of the Legal Bureau of West Papua Province, 2). Deputy Chairperson of the academic field of Bintuni, the Bintuni Law College, all of whom have provided assistance in the form of licensing the implementation of activities and accommodation at Bintuni Law College, 3). The head of the research and community service institute of Sahid University who has provided administrative facilities for the implementation of this activity.

\section{REFERENCES}

Boedi Harsono, Indonesian Agrarian Law, History of the Formation of Basic Agrarian Laws, Content and Implementation, Volume 1, National Land Law, Djambatan, Fifth Edition, Jakarta, 1994

Regional Regulation of Teluk Bintuni Regency Number 1 of 2019 concerning Recognition and Protection of Indigenous Law Communities in Teluk Bintuni Regency

Stefanus Laksanto Utomo, 2011, Land Tenure of Indigenous Peoples (Study of Legal Culture of the Samin Community in Baturejo Village, Sukolilo District, Pati Regency, Central Java Province). Diponegoro University Doctoral Program of Law Dissertation

\section{Book}

1945 Constitution of the Republic of Indonesia

Law Number 5 of 1960 concerning Basic Agrarian Principles 